\title{
İzmir'de yürütülen “Gebelerin ağız-diş sağlığının geliştirilmesi ve çürüksüz çocuklar programı”nın ara değerlendirmesi: Annelerin bilgi düzeylerindeki değișim
}

\author{
Zeliha Aslı Öcek a, Ece Eden b, Meral Türk c, Nurcan Çakırd
}

\begin{abstract}
a Prof. Dr. Ege Üniversitesi Tıp Fakültesi Halk Sağlığı Anabilim Dalı, İzmir.
b Prof. Dr, Ege Üniversitesi Diş Hekimliği Fakültesi Pedodonti Anabilim Dalı, İzmir.

c Prof. Dr, Ege Üniversitesi Tıp Fakültesi Halk Sağlığı Anabilim Dalı, İzmir.

d Dr, İzmir Bornova Belediyesi Sağlı İşleri Müdürlüğü, İzmir.
\end{abstract}

Geliş tarihi: 02.09.2015, Kabul tarihi: 26.01.2016

\section{Özet}

Amaç: “Gebelerin Ağız-Diş Sağlığının Geliştirilmesi ve Çürüksüz Çocuklar Programı”nın ilk aşamasının annelerin bilgi düzeylerindeki değiş̧im aracılığıyla değerlendirilmesi amaçlanmıştır. Yöntem: Bu eğitim müdahalesi çalışması İzmir-Bornova Belediyesi'nin Mevlana, Naldöken, Altındağ semtlerinde gerçekleştirilmiştir. Bu semtlerde yaşayan ve 2013 Nisan-Haziran aylarında gebe olan kadınların ( $\mathrm{n}=289) \% 85.8^{\prime} \mathrm{i}(\mathrm{n}=248)$ ilk aşamaya katılmıştır. 2014 yılı ŞubatMart aylarındaki ikinci așamaya \%69.4'lük (172) katılım sağlanabilmiştir. Her iki așamada da önce annelerin ağız-diş sağlığı bilgileri 12 önerme aracılığıyla ölçülmüş, dişleri muayene edilmiş, diş firçalama tekniği öğretilmiş, grup eğitimi verilmiştir. Her bir önermenin birinci ve ikinci aşamada aldığı skorların ortalamaları bağımlı örneklerde işaretli sıra testi aracılığıyla

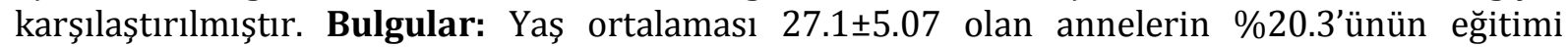
ilkokulun altındadır, \%26.2'sinin anadili Türkçe değildir, \%26.2'sinin sosyal, \%11.6'sının sağlık güvencesi yoktur. Gebelerin dişlerinin kalsiyum kaybı nedeniyle çürüdüğü şeklindeki yanlış

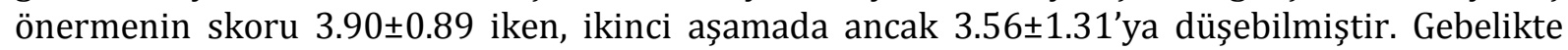
dişeti hastalığı ve sonuçlarıyla ilgili doğru önermelerin skorları artmış, çürüğe yol açan davranışlarla ilgili yanlış önermelerin skorları azalmış, yeterlilik inancında anlamlı artış olmuştur. "Dişlerimin sağlıklı olması için yapılması gerekenleri yerine getiriyorum" önermesinin skoru istatistiksel olarak anlamlı bir artış göstermemiştir. Sonuç: Program annelerin bilgi düzeylerini artırmış, ancak yanlış inanışlar ve davranış değişimi açısından yeterli sonuca ulaşılamamıştır. Sosyokültürel gelişmeyle birlikte olmayan, sadece eğitime dayalı müdahaleler ağız-diş sağlı̆̆ında sınırlı bir değișim yaratabilmektedir.

Anahtar Kelimeler: Gebelik, ağız-diş sağlığı, sağlık eğitimi, diş çürüğü

Sorumlu Yazar: Zeliha Aslı Öcek, Ege Üniversitesi Tıp Fakültesi Halk Sağlı̆̆ AD, 35100 Bornova-İzmir. Phone: +90-5334351576; E-mail: zeliha.ocek@ege.edu.tr

\section{Copyright holder Turkish Journal of Public Health}

This work is licensed under a Creative Commons Attribution-NonCommercial 4.0 International License. $(\mathrm{cc}) \mathrm{EY}-\mathrm{NC}$ properly. 


\title{
Mid-term assessment of a programme conducted in Izmir for improving oral health in pregnant women and reducing caries in children: changes in the level of knowledge of the mothers
}

\begin{abstract}
Objective: This study evaluates the first phase of a program entitled "Improving Oral Health in Pregnant Women and Reducing Caries in Children" based on the change in the level of knowledge of mothers. Methods: This interventional study was conducted in the Altındağ, Naldöken and, Mevlana districts in the Izmir-Bornova Municipality. 85.8\% ( $\mathrm{n}=248)$ of the pregnant women who lived in this neighborhood during April, May and June in $2013(\mathrm{n}=289)$ were enrolled in the program. 69.4\% $(n=172)$ participation rate was achieved in the second stage of the program during February and March 2014. In both phases, levels of knowledge of mothers were measured by using 12 propositions. The Mother's teeth were examined, toothbrushing technique was taught and oral health education was given. The average scores of the propositions contained in both questionnaires were compared for paired samples using Wilcoxon signed rank test. Results: The mean age was $27.1 \pm 5.07$. The educational level of the mothers was below primary school for $20.3 \%$ of mothers'. For $26.2 \%$, the mothers' native tongue was not Turkish, $11.6 \%$ had no health insurance. The score of the false proposition on 'tooth decays due to calcium loss in pregnancy' was decreased to $3.56 \pm 1.31$ from $3.90 \pm 0.89$. The score of true propositions on gum disease during pregnancy and its consequences increased, scores of false propositions concerning behaviors that lead to decay decreased. There was a significant increase in self-efficacy beliefs. The score for the proposition "I fulfill the things that needed to be done for the health of my teeth" did not show a statistically significant increase. Conclusion: The program increased the level of knowledge of the mothers but was not sufficient to change the false beliefs and behaviors. Unless combined with socio-cultural improvements, interventions based on oral health education can only make a limited change in oral health.
\end{abstract}

Keywords: Pregnancy, oral health, health education, dental caries

\section{Giriş}

Gebelik anne adaylarının ve çocuklarının ağız-diș sağlığı açısından çok önemli bir dönemdir. Bu dönem boyunca gerçekleșen immünolojik, hormonal ve vaskuler değişiklikler anne adaylarının diș eti dokularında enfeksiyon gelişimini hızlandırır. ${ }^{1,2} \mathrm{Bu}$ enfeksiyonların da erken doğum ve düşük doğum ağırlığı riskini arttırdığını gösteren pek çok araştırma bulunmaktadır.3,4 Ancak gebeliğin ağız-diş sağlığı açısından önemi sadece yol açtığı risklerden kaynaklanmamaktadır. Gebelik, anne ve çocukların ağız-diş sağlığının geliştirilmesi ve erken çocukluk dönemi çürüklerinin önlenmesi açısından en uygun zaman dilimi olarak görülmektedir.5,11

Erken çocukluk döneminde en sık görülen kronik hastalık olan diş çürükleri yaşam kalitesine çok büyük zararlar verebilen fiziksel, fonksiyonel ve davranışsal olumsuz sonuçlara yol açmaktadır.12,13 Neden oldukları ağrı, enfeksiyon ve apseler, iştahsızlık, gastrointestinal bozukluk, malnutrisyon, uykusuzluk gibi sonuçlar büyüme ve gelişmede aksamayı beraberinde getirmekte, geçirilen enfeksiyonlar çocuğun 
genel sağlığı açısından önemli bir tehdit oluşturmaktadır.13-16 Farklı ülkelerde yapılmış çok sayıda çalışma, erken dönem diş çürüklerinin çok büyük ölçüde önlenebilir nitelikte olduğunu ve burada annelerin anahtar rol oynadığını göstermiştir.5,7,10,17-23 Çocuğun büyümesi ile birlikte sosyal çevrenin etkisi artsa da anne halen en önemli belirleyicidir. Üstelik çocuğa sosyalleşme sürecinin ilk aşamalarında kazandırılan doğru ağız sağlığı davranışlarının daha sonraki yıllarda da kalıcılığını koruduğu gösterilmiştir. ${ }^{7}$ Fakat annelerin bu anahtar rolü gerçekleștirebilmeleri uygun bilgi ile donatılmalarına ve bir davranıș değișimi sürecinden geçmelerine bağlıdır.18 $\mathrm{Bu}$ gereksinimi karşılamak amacıyla gerçekleştirilmiş olan eğitim müdahalelerin büyük bölümünün ortak özelliği anneler ile ilk temasın gebelik döneminde başlamış olmasıdır.5-7,9-11,20 Başlangıç olarak bu aşamanın tercih edilmesi bir kaç nedenden kaynaklanmaktadır. Öncelikle anne adayları gebelik nedeniyle karşı karşıya oldukları risklerin genellikle farkında değildir ve ağızdiş sağlığ 1 sorunlarının önlenmesi ve kontrol edilmesi için desteğe gereksinim duyarlar.24-29 Bir diğer neden ise doğum öncesi izlemlerin ağı-diş sağlığı eğitimi için çok uygun bir olanak sağlamasıdır. ${ }^{8}$ Bunun yanı sıra annelerin eğitim müdahalelerine en güçlü yanıt verdikleri dönemin gebelik olduğu bildirilmiştir. ${ }^{11}$

Gebeliğe bağlı ağız-diş sağlığı sorunlarını ve erken dönem diş çürüklerini önlemeyi hedefleyen çalışmaların büyük bölümünde yoksul, etnik azınlığa ait ve/veya göçmen gibi dezavantajlı grupların hedeflendiği görülmektedir. 8,23,30,31 Bunun nedeni hem gebelikle ilişkili sorunların,11,31 hem de erken dönem diş çürüklerinin $8,9,12,13,17,20$ ve bunlardan kaynaklanan hastalık yükünün toplumun en dezavantajlı kesimlerini çok daha yoğun biçimde etkilemesidir. Ağız-diş sağlığı eşitsizliklerinin kendisini en açık şekilde erken çocukluk döneminde göstermesi ${ }^{13}$ bu gruplara yönelik müdahale çalışmalarının temel gerekçesini oluşturmaktadır.

Ülkemizde gebelikte veya anneliğin erken dönemlerinde başlayan sistematik bir ağı-diş sağlığı müdahalesi uygulanmamaktadır. Diğer ülkelerde yapılan çalışmaların sonuçları dikkate alınırsa ulusal düzeyde yürütülecek programların toplum ağız-diş sağlığ sorunlarının ve bu alanda yaşanan eşitsizliklerin çözümüne önemli bir katkı sağlayacağ 1 ortadadır. Fakat ulusal düzeydeki çalışmaların planlanabilmesi için yerel ölçekte yapılacak olan çalışmalardan elde edilecek deneyimlere gereksinim duyulmaktadır. $\mathrm{Bu}$ gereksinimden yola çıkarak, İzmir'de Bornova Belediyesi, Diş Hekimleri Odası ve Ege Üniversitesi Tıp Fakültesi Halk Sağlığı Anabilim Dalı ortaklığı ile Bornova ilçesinin sosyoekonomik dezavantajların yoğun olarak gözlendiği üç semtinde "Anne Adaylarının Ağız-Diş Sağlığının Geliştirilmesi ve Çürüksüz Çocuklar Programı" başlatılmıştır. Dört aşamadan oluşan bu programın 2013 NisanHaziran tarihleri arasında gerçekleşen ilk aşaması gebelerin, 2014 ve 2015 ŞubatNisan aylarında gerçekleşen ikinci ve üçüncü aşaması ise erken dönem çocukların ağız-diş sağlığı bakımı üzerinde yoğunlaşmıştır. Bir yıl sonra uygulanacak olan son aşama konuların tekrarı niteliğinde planlanacaktır. $\mathrm{Bu}$ yazıda aktarılan çalışmanın amacı ise programın gebelere yönelik olan ilk aşaması hakkında bilgi vermek ve bu aşamanın ardından annelerin bilgi düzeylerinde gerçekleşen değişimi temel alan ara değerlendirme sonuçlarını aktarmaktır.

\section{Gereç ve Yöntem}

Tasarım ve Araştırma grubu

$\mathrm{Bu}$ eğitim müdahalesi çalışması sosyoekonomik dezavantajların yoğun olarak gözlendiği ve İzmir-Bornova Belediyesi'nin sosyal hizmet sunduğu Mevlana, Naldöken ve Altındağ semtlerinde gerçekleştirilmiştir. Mevlana ve Naldöken Doğu illerinden çok yoğun göç almaktadır. Altındağ ise ağırlıklı olarak Balkan ülkelerinden gelmiş olan göçmenlerin yaşadığı, fakat Doğu illerinden de göç alan bir semttir. Araştırmanın evrenini de bu semtlerde yaşayan tüm anne adayları oluşturmuş ve 2013 Nisan-Haziran 
aylarında gebe olan 289 kadın, belediyenin alan ebeleri aracılığı ile semtlerindeki kültür merkezlerine eğitim almak üzere davet edilmiş, \%85.8 (n=248) düzeyinde katılım gerçekleşmiştir. Türkçe bilmeyen ve yanında iletişimi sağlayan herhangi bir yakını bulunmayan dört kadın çalışma kapsamı dışında bırakılmıştır. Programın 2014 Şubat-Mart aylarında gerçekleşen ikinci aşamasına ilk aşamaya katılmış olan kadınların \%69.4'ü (n=172) katılmıștır.

Araştırma ile ilgili olarak Ege Üniversitesi Tıp Fakültesi Etik Kurulu'ndan (karar numarası: 13-2.1/18) onay alınmıștır.

\section{Eğitim Müdahalesi}

Araştırma ekibinin ve İzmir Diş Hekimleri Odası Toplum Ağız-Diş Sağlığı komisyonu üyelerinin katıldığı dört toplantıda müdahalenin öğrenim hedefleri ve eğitim teknikleri belirlenmiş, programın hem tüm süreçte hem de ilk aşamada yer alan bileșenlerin zamanlarına karar verilmiş, saptanan ağız-diş sağlığı sorunlarının tedavisi için izlenecek yol şekillendirilmiştir. Komisyonun on üç üyesi programa eğitici olarak katkı verebileceğini bildirmiştir. Bu diş hekimlerine yönelik üç günlük bir eğitici eğitimi düzenlenmiştir. İzmir Diş Hekimleri Odası'nda gerçekleşen eğitimin ilk iki gününde halk sağlığı öğretim üyesi olan iki eğitici tarafından yetişkin öğrenme ilkeleri açıklanmış, beceri eğitiminde kullanılan teknikler uygulamalı olarak gösterilmiştir. Son günde ise bir periodontoloji uzmanı gebelikte ağız-diş sağlığı sorunlarına yaklaşım başlıklı bir ders anlatmış, diş firçalama demonstrasyonu yaparak, kabul gören en güncel teknikleri göstermiştir. Bu dersin ardından her bir diş hekimi birer kișiye (oda sekreteri, bina görevlisi, vb) koçluk ilkeleri çerçevesinde diş firçalama eğitimi vermiştir. Eğitim bir pedodonti uzmanının erken dönem diş çürüklerinin önlenmesi başlıklı dersi ve değerlendirme oturumu ile sonlanmıştır. Eğitici eğitimine katılan ve ilk aşamaya eğitici olarak katkı veren diş hekimlerine ara değerlendirme sonuçlarının paylaşıldığı bir toplantıda İzmir Diş Hekimleri Odası
Başkanı ve Bornova Belediyesi Başkanı tarafından teşekkür belgeleri verilmiştir.

Eğitimin ilk aşamasının temel amacı anne adaylarına gebelik dönemindeki ağızdiş sağlığı riskleri ve doğru davranışlar hakkında bilgi kazandırmaktır. $\mathrm{Bu}$ çerçevede katılımcıların eğitimin ardından "gebeliğe bağlı ağız-diş sağlı̆̆ risklerinin ve bunların sonuçlarının farkında olmaları", "gebelikte diş kaybının kaçınılmaz olduğu yönündeki inanışın doğru olmadığını bilmeleri" ve "ağız-diş sağlığı açısından doğru hijyen ve beslenme davranıșının nasıl olması gerektiğini açılayabilmeleri" hedeflenmiştir. Çok kapsamlı bir içerikte olmamakla birlikte çocuklarda erken dönem diş çürüklerinin önlenmesine yönelik öğrenim hedefleri de eğitime dahil edilmiştir. Bunlar, "erken dönem diş çürüklerine yol açan davranışları açıklayabilme", "bu çürüklerin yol açtıkları sağlık risklerini sayabilme", "ebeveynlerin çocuklarının dişlerinin çürümesini önleyebileceğinin farkında olma", "süt dişlerinin temizlenmesi gerektiğini bilme" şeklinde sıralanmaktadır.

Grup eğitimlerinin içeriğini araştırma ekibinde yer alan ve biri pedodonti diğeri ise halk sağlığı alanında bilim doktoru olan iki öğretim üyesi öğrenim hedefleri çerçevesinde birlikte oluşturmuştur. Programdaki tüm grup eğitimlerini de bu iki öğretim üyesi dönüşümlü olarak yürütmüştür. Eğitim erken dönem diş çürüklerinin sonuçlarını gösteren beş dakikalık bir film gösterimi ile bașlamakta, filmi tanıșma ve eğitim amacının açıklanması izlemektedir. Eğitimde anlatım ve soru cevap tekniklerinin yanı sıra doğru beslenme seçeneklerini gösteren basit bir kart oyunundan yararlanılmaktadır. Film ve oyun araştırıcılar tarafından hazırlanmıştır. Pilot uygulama amaciyla Mevlana Mahallesi'nde yaşayan ve 8-9 aylık gebe olan altı kadından oluşan bir gruba verilmiştir. Diğer araștırıcılar bu pilot eğitime gözlemci olarak katılmıştır. Annelerden alınan geribildirimler ve gözlemler dikkate alınarak eğitim içeriği basitleştirilmiş ve kısaltılmıştır. 
Müdahale $\quad$ Süreci: Eğitim merkezlerine gelen anne adaylarına önce birebir anket uygulanmış, diş hekimlerinin uyguladığ gereksinimleri hakkında bilgi verilmiș, Bornova Belediyesi'nden ve periodontitis vakaları için Ege Üniversitesi Diş Hekimliği Fakültesi'nden ücretsiz hizmet alabilecekleri aktarılmıștır. Ardından her bir anne adayına eğitici eğitimi almış olan diş hekimleri tarafından çene modelleri üzerinde bire bir diş firçalama eğitimi verilmiştir. Anne adayları son olarak 5-15 kişilik gruplar halinde 45-60 dakika süren grup eğitimine katılmıştır. Süreci tamamlayan annelere bebek bezi, pișik kremi, bebek şampuanı ve sabunu, ıslak mendil, meme pedi, diş macunu ve fırçasından oluşan hediye paketleri verilmiştir.

\section{Istatistiksel analiz}

Bilgi ve yeterlilik algısı değişimini değerlendirmek amacıyla, programın ilk aşamasında eğitim öncesinde uygulanmış olan anketlere verilen yanitlar annelerin 911 ay sonra katıldıkları ikinci aşamada yine eğitim öncesinde verdikleri yanıtlar ile karşılaştırılmıştır. Bu karşılaştırmaya iki aşamaya da katılan 172 anne alınmıştır.

İlk aşamada uygulanan ankette katılımcıların sosyodemografik özelliklerini (yaş, medeni durum, çocuk sayısı, eğitim düzeyi, eşin eğitim düzeyi, İzmir'de yaşama süresi, anadil, çalışma durumu ve meslek, eşin mesleği, aile yapısı, sosyal güvence ve sağlık güvencesi varlığı ve gelir) belirlemeye yönelik sorular yer almıştır. Hane reisinin işine göre sosyal sınıf belirlenmiştir. $\mathrm{Bu}$ değişken; kendi hesabına çalışanlar (yanında işçi çalıştırmayanlar), mavi yakalılar (daha çok el emeği ile üretim yapanlar), işsiz ve marjinaller (gelir getirici işi olmayanlar, sürekli olmayan ve kayıt dişı işlerde çalışanlar), işverenler (yanında işçi çalıştıranlar) ve beyaz yakalılar (kafa emeği ile üretim yapanlar) olmak üzere dört grupta incelenmiştir. ${ }^{32}$

Her iki aşamada da uygulanan ankette bilgi ve yeterlilik inancını değerlendiren 12 önerme bulunmaktadır.
$\mathrm{Bu}$ önermelerin belirlenmesi için literatür taraması yapılarak öğrenim hedefleri çerçevesindeki sorulardan bir havuz oluşturulmuş, ardından çok disiplinli bir ekip (pedodonti uzmanı, periodontoloji uzmanı, halk sağlığı doktoru, belediye diş hekimi) bu havuzdaki uygun soruları seçmiş, öneri şeklinde ifade etmiş ve dört başlık ("yanlış inanışlar", "gebelikte artan risk ve sonuçları", "süt dişlerinin bakımı", "ağız-diş bakımı ile ilgili yeterlilik inancı") altında gruplandırmıștır. Önermelerin seçiminde gebelik ve erken çocukluk dönemi ile ilgili olma, Türkiye'de ve araştırma bölgesinde sık görülen yanlış inanış ve davranışları yansıtma kriteri dikkate alınmıştır. Kadınlar her bir önermeye ne düzeyde katıldıklarını beşli Likert Skalası üzerinde belirtmiştir (1= kesinlikle katılmıyorum; 2= katılmıyorum; $3=$ ne katılıyorum ne de katılmiyorum; 4= katılıyorum; 5= kesinlikle katılıyorum). Bornova- 25 nolu Mevlana Aile Sağlığ Merkezi'ne kayıtlı ve araştırma grubunda yer almayan 15 gebede anketin pilot uygulaması yapılmış, anlaşılmayan iki önerme çlkarılmış, üç önermenin de ifadeleri sadeleștirilmiștir.

Anketleri

programin yürütücülerinden olan yedi araştırıcı yüz yüze görüşme tekniği ile uygulamıştır $(\mathrm{Bu}$ araştırıcılardan üçü ara değerlendirmenin yazım aşamasında yer almamıştır). Tüm araștırıcılar program geliştirme ve anket oluşturma süreçlerine aktif olarak katıldığı için anketör eğitimi uygulanmamıştır. Türkçesi yetersiz olan altı kadına yanlarında bulunan yakınları (kızı, görümcesi ve eltisi) aracılığı ile anket uygulanmıştır.

Her bir önermenin birinci ve ikinci aşama eğitimlerinden önce belirlenen skor ortalamaları arasındaki farkın anlamlı olup olmadığı değerlendirilmiştir. Bu farkın tüm önermelerde normal dağılıma uygunluk göstermemesi nedeniyle bağımlı örneklerde işaretli sıra testi uygulanmıştır.

\section{Bulgular}

Araştırma grubunun yaş ortalaması $27.13 \pm 5.07$ (en düşük yaş 18, en yüksek yaş 41) olarak belirlenmiștir. Tablo 1'de 
görüldügü gibi, annelerin $\% 20.3$ 'ünün eğitim düzeyi ilkokulun altındadır, \%65.1'i ise ilkokul veya ortaokul mezunudur. Yaklaşık olarak her dört anneden birinin anadilinin Türkçe olmadığı ve beş anneden birinin de İzmir'de üç yıl veya daha kısa bir süredir yaşadığı saptanmıştır. Diğer sosyoekonomik değişkenler değerlendirildiğinde \%92.4'ünün çalışmadığı, \%63.4'ünün eşinin mavi yakalıniteliksiz hizmet iş̧̧isi olduğu, \%26.2'sinin sosyal güvencesinin, \%11.6'sının da sağllk güvencesinin bulunmadığı, aylık geliri asgari ücretin altında olanların grubun \%33.7'sini oluşturduğu görülmüştür.

$\begin{array}{ccc}\text { Programın } & \text { ilk aşamasının } \\ \text { değerlendirilmesinde } & \text { öncelikle bilg }\end{array}$
düzeyinde gerçekleşen değişim sorgulanmıștır (Tablo 2). Kalsiyum kaybı nedeniyle gebelerin dişlerinin kolay çürüdüğü șeklindeki yanlıș önermeye verilen skor ilk aşamada $3.90 \pm 0.89$ iken, ikinci aşamada $3.56 \pm 1.31$ 'ya düşmüștür. Likert Skalasında 3'ün "ne katılıyorum ne de katılmıyorum" ifadesini yansittığı dikkate alınırsa bu inanışın yanlış olduğu yönünde bir bilgi değişimi gerçekleşmediği görülmektedir. Gebelik döneminde artan dișeti hastalığı riskiyle (3.69'dan 4.07'e) ve gebelikteki diş sorunlarının bebek üzerindeki etkileri ile (2.87'den 3.28'e) ilgili doğru önermelerde skorlar anlamlı artış göstermiştir. Erken dönem diş çürüklerine yol açan davranışlar ile ilgili yanlıș önermelerin skorları anlamlı olarak azalmıştır; "emziğe alıştırmak için şeker sürülebilir" önermesinin skoru $2.43 \pm 1.35$ 'den $1.83 \pm 1.36$ 'ya, "bebekler gece biberonla yatırılabilir" önermesinin skoru $2.25 \pm 1.25$ 'den $1.68 \pm 1.18$ ' e düșmüștür. İnanç ve yeterlilikle (sağlıklı dișlere sahip olmak için yapılması gerekenleri bilme, dişlerinin sağlıklı olmasını sağlayabileceğine inanma) ilgili önermelerde de anlamlı artış olmuştur. Yeterlilikle bağlantılı olarak davranıș değișimi de değerlendirilmiș, fakat "dișlerimin sağlıklı olması için yapılması gerekenleri tam olarak yerine getiriyorum" ifadesinin skorunun $2.68 \pm 1.29$ 'dan sadece $2.86 \pm 1.25$ 'e çlkabildiği ve bu farkın da istatistiksel olarak anlamlı olmadığı görülmüştür.

\section{Tartışma}

Bornova'da yaşayan sosyoekonomik açıdan dezavantajlı anneleri hedefleyen bu program hem süreç hem de sonuç değerlendirmesi aracılığı ile öğretici bulgular sunma potansiyeli taşıyan bir uygulamadır. Programın gebelere yönelik olan ilk aşamasını değerlendiren bu çalışmada bundan sonraki aşamaların ve ulusal düzeyde yürütülebilecek bir müdahale programının şekillendirilmesine yol gösteren ipuçları elde edilmiştir.

Ağız-diş sağlığı ile ilgili yanlış inanışların değiştirilmesi bu programın temel hedefleri arasında yer almaktadır. Pek çok ülkede olduğu gibi ülkemizde de gebeliğin dişlerde kalsiyum kaybına ve dolayısıyla çürük riskinde artışa yol açtığı inanışı çok yaygındır.1,26,28,29 Benzer şekilde, bu çalışmada eğitim öncesinde yapılan değerlendirmede kalsiyum kaybına bağlı çürük riski inanışının anne adayları tarafından benimsenmiş olduğu, eğitimden yaklașık bir yıl sonra da hakimiyetini koruduğu görülmüştür.

Çalışmada değiştirilmesi hedeflenen diğer iki yanlış inanış erken dönem diş çürüklerinin en önemli nedenleri arasında yer alan çocuğu biberonla uyutma ve emziğe tatlı gıda maddeleri sürme davranışları ${ }^{7-}$ 8,13,19 ile ilgilidir. Malezya'da yapılan bir çalışmada ${ }^{24}$ anne babaların yarısı uykuda biberon kullanmanın diş çürügüne yol açtığını bilmediğini bildirmiş, fakat emziği gıdalarla tatlandırma davranışına sadece $\% 2$ oranında rastlanmıştır. ABD'de göçmen anneleri kapsayan bir çalıșmada ise katılımcıların \%88'i biberonla uyutmanın doğru olmadı̆̆ını belirtmiștir. ${ }^{25}$

Bu çalışmalar ile karşılaştırıldığında eğitim öncesinde araştırma grubunda hem biberonla uyutma hem de emziği tatlandırma davranışlarının daha yaygın bir şekilde benimsendiği görülmüştür.

Eğitimin ardından bu yanlış inanışlara katılma düzeyi azalmış, fakat varlığını korumuştur. Bu sonuçlar yerleşmiş olan yanlış inanışları değiştirmek için tek bir eğitimin ve tek bir iletişim kanalının yetersiz kaldığını yansıtmaktadır. 
Tablo 1. Araştırmaya katılan anne adaylarının müdahale öncesinde sosyodemografik özelliklerine göre dağılımı

\begin{tabular}{|c|c|c|c|}
\hline Değişken & & $\mathbf{N}$ & $\%$ \\
\hline \multirow{5}{*}{ Yaş } & 20 altı & 8 & 4.7 \\
\hline & $20-24$ & 51 & 29.7 \\
\hline & $25-29$ & 54 & 31.4 \\
\hline & $30-34$ & 46 & 26.7 \\
\hline & 35 ve üzeri & 13 & 7.5 \\
\hline \multirow[t]{3}{*}{ Medeni durum } & Resmi nikah & 168 & 97.7 \\
\hline & İmam nikahı & 4 & 2.3 \\
\hline & 0 & 53 & 30.8 \\
\hline \multirow[t]{3}{*}{ Çocuk sayısı } & 1 & 50 & 29.1 \\
\hline & 2 & 37 & 21.5 \\
\hline & 3 ve üzeri & 32 & 18.6 \\
\hline \multirow{5}{*}{ Eğitim düzeyi } & Okur-yazar değil & 20 & 11.6 \\
\hline & Okur-yazar & 15 & 8.7 \\
\hline & İlkokul mezunu & 73 & 42.4 \\
\hline & Ortaokul mezunu & 39 & 22.7 \\
\hline & Lise mezunu ve üzeri & 25 & 14.5 \\
\hline \multirow{5}{*}{ Eşinin eğitim düzeyi } & Okur-yazar değil & 3 & 1.7 \\
\hline & Okur-yazar & 8 & 4.7 \\
\hline & İlkokul mezunu & 79 & 45.9 \\
\hline & Ortaokul mezunu & 43 & 25.0 \\
\hline & Lise mezunu ve üzeri & 39 & 22.7 \\
\hline İzmir'de yaşama & 1 ylldan az & 7 & 4.1 \\
\hline \multirow[t]{3}{*}{ süresi } & 1-3 yll & 23 & 13.4 \\
\hline & 4-6 yll & 22 & 12.8 \\
\hline & 7 yll ve üzeri & 120 & 69.8 \\
\hline \multirow[t]{2}{*}{ Anadili } & Türkçe & 127 & 73.8 \\
\hline & Diğer (Kürtçe, Arapça, Zazaca) & 45 & 26.2 \\
\hline \multirow[t]{3}{*}{ Çalışma durumu } & Ev kadını & 159 & 92.4 \\
\hline & Çalışıyor* & 13 & 7.6 \\
\hline & Mavi yakalı & 109 & 63.4 \\
\hline \multirow[t]{3}{*}{ Sosyal Sinıf } & İşsiz/marjinal & 43 & 25.0 \\
\hline & Kendi hesabına çalışan & 16 & 9.3 \\
\hline & İșveren, beyaz yakalı & 4 & 2.4 \\
\hline \multirow{3}{*}{ Aylık gelir } & Asgari ücret altı & 58 & 33.7 \\
\hline & Asgari ücret ve 2 kat üzeri & 76 & 44.2 \\
\hline & Asgari ücretin 2 katından fazla & 38 & 22.1 \\
\hline \multirow[t]{2}{*}{ Sosyal güvence } & Yok & 45 & 26.2 \\
\hline & Var & 127 & 73.8 \\
\hline \multirow[t]{2}{*}{ Sağlık Güvencesi } & Yok & 20 & 11.6 \\
\hline & Var & 152 & 88.4 \\
\hline Toplam & & 172 & 100.0 \\
\hline
\end{tabular}

*7 ücretli işçi, 4 yevmiyeli işçi, 2 memur 
Tablo 2. Bilgi ve özyeterlilik önermelerinin eğitim öncesi ve sonrası ortalama puanları

\begin{tabular}{|c|c|c|c|}
\hline \multirow[t]{2}{*}{ Önerme } & $\begin{array}{l}\text { Ĕgitim } \\
\text { Öncesi }\end{array}$ & $\begin{array}{l}\text { Eğitim } \\
\text { Sonrası }\end{array}$ & \multirow[t]{2}{*}{$\begin{array}{c}\text { Bağımlı } \\
\text { örneklerde } \\
\text { işaretli sıra testi }\end{array}$} \\
\hline & Ort (SS) & Ort (SS) & \\
\hline \multicolumn{4}{|l|}{ Yanlış inanışlar } \\
\hline $\begin{array}{l}\text { Gebelik sırasında bebek, annenin dişlerindeki } \\
\text { kalsiyumu kullandığı için annenin dişleri daha } \\
\text { zayıflar ve çürür. }\end{array}$ & $\begin{array}{c}3.90 \\
(0.89)\end{array}$ & $\begin{array}{c}3.56 \\
(1.31)\end{array}$ & $\mathrm{p}=0.010$ \\
\hline $\begin{array}{l}\text { Bebekleri emziğe alıștırmak için emziğin } \\
\text { üzerine şeker, bal vb. sürülebilir. }\end{array}$ & $\begin{array}{c}2.43 \\
(1.35)\end{array}$ & $\begin{array}{c}1.83 \\
(1.36)\end{array}$ & $\mathrm{p}<0.001$ \\
\hline $\begin{array}{l}\text { Geceleri iyi uyumalarını sağlamak için bebekler } \\
\text { biberonla yatırılabilir. }\end{array}$ & $\begin{array}{c}2.25 \\
(1.25)\end{array}$ & $\begin{array}{c}1.68 \\
(1.18)\end{array}$ & $\mathrm{p}<0.001$ \\
\hline \multicolumn{4}{|l|}{ Gebelikte artan risk ve sonuçları hakkında bilgi } \\
\hline $\begin{array}{l}\text { Gebelik döneminde kadınlar diş eti } \\
\text { hastalıklarına daha kolay yakalanır. }\end{array}$ & $\begin{array}{c}3.69 \\
(0.94)\end{array}$ & $\begin{array}{c}4.07 \\
(1.14)\end{array}$ & $\mathrm{p}<0.001$ \\
\hline $\begin{array}{l}\text { Gebelik döneminde diş sorunları çocukta erken } \\
\text { doğum, düşük kiloda doğum gibi sorunlara yol } \\
\text { açabilir. }\end{array}$ & $\begin{array}{c}2.87 \\
(0.99)\end{array}$ & $\begin{array}{c}3.28 \\
(1.42)\end{array}$ & $\mathrm{p}<0.001$ \\
\hline \multicolumn{4}{|l|}{ Süt dişlerinin bakımı hakkında bilgi } \\
\hline Süt dişleri de kalıcı dişler gibi temizlenmelidir. & $\begin{array}{c}3.82 \\
(1.04)\end{array}$ & $\begin{array}{c}4.15 \\
(1.23)\end{array}$ & $\mathrm{p}=0.004$ \\
\hline $\begin{array}{l}\text { Süt dişleri çıkar çıkmaz diş temizliğine } \\
\text { başlanmalıdır. }\end{array}$ & $\begin{array}{c}3.18 \\
(1.21)\end{array}$ & $\begin{array}{c}3.74 \\
(1.48)\end{array}$ & $\mathrm{p}<0.001$ \\
\hline $\begin{array}{l}\text { Aynı kaşığın kullanımı vb yollarla annenin } \\
\text { ağzındaki çürük yapıcı mikroplar bebeğe } \\
\text { geçebilir. }\end{array}$ & $\begin{array}{c}3.99 \\
(1.07)\end{array}$ & $\begin{array}{c}4.51 \\
(0.88)\end{array}$ & $\mathrm{p}<0.001$ \\
\hline \multicolumn{4}{|l|}{ Ağız-diş bakımı ile ilgili özyeterlilik inancı } \\
\hline $\begin{array}{l}\text { Sağlıklı dişlere sahip olmak için neler yapılması } \\
\text { gerektiğini biliyorum. }\end{array}$ & $\begin{array}{c}3.80 \\
(1.16)\end{array}$ & $\begin{array}{c}4.37 \\
(0.96)\end{array}$ & $\mathrm{p}<0.001$ \\
\hline $\begin{array}{l}\text { Dişlerime daha iyi bakarsam daha sağlıklı } \\
\text { olmalarını sağlayabilirim. }\end{array}$ & $\begin{array}{c}4.12 \\
(0.91)\end{array}$ & $\begin{array}{c}4.62 \\
(1.61)\end{array}$ & $\mathrm{p}<0.000$ \\
\hline $\begin{array}{l}\text { Çocuğumun sağlıklı dişlere sahip olmasını } \\
\text { sağlayabilirim. }\end{array}$ & $\begin{array}{c}3.91 \\
(1.00)\end{array}$ & $\begin{array}{c}4.38 \\
(0.91)\end{array}$ & $\mathrm{p}<0.000$ \\
\hline $\begin{array}{l}\text { Sağlıklı dişlere sahip olmak için yapılması } \\
\text { gerekenleri tam olarak yerine getiriyorum. }\end{array}$ & $\begin{array}{c}2.68 \\
(1.29)\end{array}$ & $\begin{array}{c}2.86 \\
(1.25)\end{array}$ & $\mathrm{p}=0.195$ \\
\hline
\end{tabular}


Anne adaylarının gebelik ile birlikte artan diş eti hastalığı riski ve bu hastalıkların erken doğum, düşük doğum ağırlığı gibi sonuçlara yol açma potansiyeli hakkında bilgi sahibi olmaması hem ülkemizde hem de yurtdışında yapılmış olan çalışmalarda vurgulanan bir sorundur. ${ }^{1,26,28,29} \quad \mathrm{Bu}$ çalışmada $\mathrm{da}$ katılımcıların gebeliğin diş eti sağlığı üzerinde yarattığı riskin ve erken doğum gibi olası sonuçlarının farkında olmadıkları görülmüştür. Eğitimden yaklaşık bir yıl sonra yani gebeliğin tamamlanmasının ardından yapılan değerlendirmede anneler arasında diş eti hastalığı riski konusunda bir farkındalık oluştuğu, fakat annelerin bu hastalıkların yaratabileceği tehlikelerin halen yeterince farkında olmadığı görülmüştür. $\mathrm{Bu}$ da gözlenen değişimde eğitimin yanı sıra annelerin kendi deneyimlerinin de rol oynadığ düşündürmektedir.

Malezya $^{24}$ ve ABD'de $^{25}$ yapılan iki çalışmada annelerin çok büyük bölümünün süt dişlerinin sürer sürmez temizlenmesi gerektiğini bildirmiştir. Bornova'da ise eğitim öncesinde süt dişlerinin temizlenmesi gerektiği düşüncesinin anne adayları açısından oldukça yabancı olduğu görülmüştür. Eğitimin ardından süt dişlerinin temizlenmesi gerektiği ve anneden bebeğe diş çürüklerinden sorumlu bakterilerin geçebileceği konusunda yaygın bir kabul sağlanmış, fakat süt dişlerinin temizlenmesine bu dişler sürer sürmez başlanması gerektiği konusunda anneler tam olarak ikna edilememiştir.

Yetişkinlerde ağız-diş sağlığı davranışı değişimin çok kapsamlı bir müdahale süreci gerektirir ve bașarıya ulaşmak her zaman mümkün değildir.18,33 $\mathrm{Bu}$ çalışmada da eğitimin ardından annelerin kendi ağız-diş sağlığı bakımları ile ilgili yeterlilik inancı artmış, ama bu artış önemli bir davranış değişimi olarak yansımamıştır. Diğer yandan görüşülen anneler yaklaşık olarak son 4-8 ay içinde doğum yapmıştır. Çocuk bakımı ile ilgili yükün en yoğun olduğu bu dönemde öz bakım davranışında bir gelişme gerçekleşmesi olasılığının düşüklüğü dikkate alınmalıdır.

Erken dönem diş çürüklerini önlemek için annelerin ve/veya çocuğun bakımından sorumlu olan diğer kişilerin bilgi ve davranış düzeylerini geliștirmeyi amaçlayan çalışmalarda çok çarpıcı başarılar elde edilememiştir.13,14,34 Davranışlardaki gelişme kısa süre ile sınırlı kalmakta, hedeflenen davranışların sadece bir kaçında değișim sağlanabilmekte, çürük sıklığında kontrol gruplarına göre önemli bir fark gözlenmemektedir.14,18,34 Bornova'da gerçekleştirilen bu programın ilk aşamasında da benzer bir sonuç elde edilmiştir; yanlış inanışları değiștirme ve bilgi kazandırma açısından önemli bir adım atılmış, fakat henüz istenen düzeyde gelişme sağlanmamıştır. $\mathrm{Bu}$ durumun en önemli nedeni, dört aşamalı olan müdahale sürecinin ilk etkilerinin değerlendirilmiş olmasıdır. Program içeriği diğer çok aşamalı müdahale örneklerinde olduğu gibi gelişimsel dönemler dikkate alınarak oluşturulmuştur.7,9,17,18,21,35 İlk aşamada gebelikte ağız-diş sağlığı üzerinde yoğunlaşılmış, erken dönem diş çürükleri hakkındaki tartışma diğer aşamalarda üzerinde yoğunlaşılcağ 1 için kısa tutulmuştur. Birleşik Krallık'ta uygulanmış olan iki çalışma annelerin diş çürükleri hakkındaki bilgilere doğum sonrası dönemde daha açı olduğunu düşündürmektedir. İlk çalışmada gebelere verilen eğitimin ardından katılımcıların önemli bölümü eğitimin dișlerin öncelikli olduğu bir dönemde, örneğin sürme zamanında verilmesini önermiştir. ${ }^{22}$ İkinci çalışmada ise gebelikte herhangi bir temas kurulmaksızın sekiz aylık bebeklerin rutin ev ziyaretlerine ağız-diş sağlığı eğitimi dahil edilmiş ve bebekler bir yaşına geldiğinde annelerin davranışlarında olumlu bir değişim gözlenmiștir. ${ }^{21}$ Diğer yandan ilk temasın gebelik döneminde gerçekleşmesi doğum sonrası verilecek eğitim için bir temel oluşturacak ve hatalı davranışların henüz başlamadan önlenebilmesine olanak sağlayacaktır.

Ağız-diş hastalıkları aile ve toplum düzeyinde birçok risk faktörünün birlikte 
rol oynadığı karmaşık sağlık sorunlarıdır. ${ }^{18}$ $\mathrm{Bu}$ nedenle özellikle dezavantajlı toplumlarda ağız-diş sağlığı davranışlarını belirleyen sosyoekonomik bileșenleri ele almayan müdahalelerden ancak sinırlı düzeyde sonuçlar alınabilmektedir. ${ }^{18,31} \mathrm{Glda}$ güvencesizliği gibi çok sayıda stres etkeni ile karşı karşıya olan ailelerin ağız-diş sağlğını öncelikli bir konu olarak ele alması düşük bir olasılıktır. ${ }^{18}$ Bu çalışmada da eğitim, gelir ve sosyal sınıf açısından dezavantajlı bir grup hedeflenmiştir. Çalışmanın sosyoekonomik bileșenlere yönelik herhangi bir müdahalesi olamamıştır, fakat eğitim müdahalesi, Bornova Belediyesi'nin bu bölgede yürüttüğ̈ sosyal hizmetler ve gebe-bebek izlemi amaçlı ev ziyaretleri ile bütünlük göstermektedir. Diğer yandan aile sağlığı merkezlerince yürütülen gebe ve bebek izlemleri ile bir eşgüdüm sağlanamadığı sürece bu tip müdahalelerin uzun erimli ve ülke çapında yaygın bir sonuca ulaşması oldukça güçtür. Diğer ülkelerde yapılan toplum tabanlı müdahalelerde de ağız-diș sağlı̆̆ı eğitiminin gebe ve bebek izlemi amaciyla gerçekleştirilen ev ziyaretleri ile desteklenmesinin başarı olasılığını arttırdığı görülmüştür. ${ }^{21,31}$

Ders aktarımı, broşür dağıtımı gibi geleneksel tekniklerden yararlanan ağız-diş sağlığı müdahalelerinin ancak sınırlı bir etki yaratabildiğinin görülmesi üzerine farklı yaklaşımlar üzerinde durulmaya başlanmıştır. ${ }^{18-34}$ Bornova'da uygulanan bu programın da diğer aşamalarında eğitim yaklaşımının modifiye edilmesi gerektiği ortadadır. Önerilen farklı yaklaşımlar içinde motivasyonel görüşme tekniği öne çıkmaktadır. ${ }^{34}$ Davranış değiştirme motivasyonunu ortaya çıkartmayı amaçlayan bireysel danışmanlık oturumuna dayalı bu tekniğin ${ }^{34}$ Bornova'da uygulanması için gerek organizayon gerekse iş gücü bakımından uygun bir alt yapı mevcut değildir. Bu nedenle üçüncü aşama eğitimlerinde motivasyonel görüşme tekniğinin ilkelerinden yararlanılmış, fakat oturumlar dört kişilik gruplarla yürütülmüştür. $\quad \mathrm{Bu}$ aşamanın ara değerlendirme sonuçları yaklaşım değişiminin etkili olup olmadığını ortaya koyacaktır. $\begin{array}{ccc} & \text { Anne Adaylarının Ağız-Diş } \\ \text { Sağlığının Geliştirilmesi ve Çürüksüz }\end{array}$ Çocuklar Programı"nın ilk aşamasını değerlendiren bu çalışmanın sonuçlarının hem katılıma, hem de bildirime bağlı yan tutma hatasından etkilenmiş olması güçlü bir olasılıktır. Çalışma ikinci aşamaya devam etmiş olan anneleri kapsamaktadır ve bu annelerin ağız-diş sağlığı konusunda daha duyarlı oldukları düşünülebilir. Diğer yandan bu konu ile ilgili bir bulgu olmasa da anneleri katılıma yönlendiren en güçlü etmenin dağıtılan hediye paketleri olduğu gözlenmiştir. Bildirime bağlı yan tutma olasılığ ise ilk aşamanın ardından annelerin araștırıcıların istedikleri yönde yanıt vermiș olabilmelerine bağlıdır. Ana dili Türkçe olmayan 45 annenin her ne kadar yeterli iletişim kurabilseler de eğitim içeriğini izlemekte zorlandıkları düşünülebilir. $\mathrm{Bu}$ nedenle dil sorunu eğitimin gerçek potansiyelinden daha düşük düzeyde ölçülmesine yol açmış olabilecek bir sınırlılıktır. Bulguların geçerlilik analizi yapılmamış bir ölçek aracılığı ile değerlendirilmiş olması bu çalışmanın bir diğer önemli sinırlılığıdır. Bununla birlikte bilgi ve yeterlilik inancını değerlendiren 12 önermenin aşamalı bir süreç izlenerek belirlenmiş olmasının bu sinırlılığı kısmen de olsa azalttığı düşünülebilir.

Programın bu ilk aşama değerlendirmesi eğitimin başarısı konusunda karar vermeye değil, süreci izlemeye, sorunlu alanları ve çözüm yollarını belirlemeye yönelik bir çalışma olarak ele alınmalıdır. Çalışmada karşılaşılan en önemli güçlük katılımın sağlanması olmuştur. Belediye ebelerinin kendi bölgelerindeki annelerle yakın ilişki içinde olması ve hediye paketlerinin verilmesi bu güçlüğün büyük oranda aşılmasını sağlamıştır. Belediye personelinin varlığı çok sayıda annenin çocuklarıyla birlikte eğitim merkezinde bulunduğu zamanlarda organizasyonu kolaylaştırmıştır. Katılımcı sayısı yüksek olan grup eğitimleri yeterince etkin olamamıştır. Bundan sonraki așamalarda katılımcı sayısının dört ile sınırlı tutulmasina, annelerin kendilerini ifade etmelerine olanak sağlanmasına karar verilmiştir. Eğitim düzeyi düşük olan 
anneler anket sorularını algılamakta zorlanmış, anket süresinin uzaması akıșı aksatmiştır. Diğer aşamalarda değerlendirmenin daha az zaman alan araçlarla gerçekleştirilmesi uygun olacaktır. Diş muayeneleri sonucunda tedavi gereksinimi saptanan anne adaylarma belediye diş hekimi ve Ege Üniversitesi Diş Hekimliği Fakültesi tarafından hizmet verileceği belirtilmiş, fakat sadece bir anne başvurmuştur. $\mathrm{Bu}$ sorun ancak annelerin yaşadıkları bölgede kolay ulaşabildikleri bir hizmet ve başvurunun gerçekleşip gerçekleşmediğini izleyen bir birinci basamak sağlık çalışanı bulunduğu koşullarda çözülebilecektir.

Sonuç olarak, bu çalışmada annelerin gebelikte diş eti hastalıkları hakkındaki farkındalık düzeyi artmış, erken dönem diş çürüklerinin nedenleri ve koruyucu davranışlar hakkındaki bilgileri gelişmiştir, fakat eğitim müdahalesi annelerin kendi ağız-diş sağlığ davranışlarında ve gebelikte kalsiyum kaybına bağlı artan çürük riski inanışında önemli bir değişim sağlayamamıştır. $\mathrm{Bu}$ sonuçlar ülkemizde gebeliğe bağlı ağız-diş sağlığı sorunlarını ve erken dönem diş çürüklerini önlemeye yönelik programlarda dikkate alınması gereken noktalara işaret etmiştir. Buna göre, eğitim müdahaleleri gebeliğin erken dönemlerinde hatta gebelik öncesinde başlamalı, doğumun ardından gelişimsel dönemler temel alınarak devam etmelidir. Bilgi aktarımı davranış değișimi gerçekleşmesi için yeterli olamamaktadır. Anneleri ve çocuğun bakımından sorumlu olan diğer kişileri davranış değişimine motive edebilen yaklaşımlar izlenmelidir. Birinci basamak sağllk hizmetleriyle eşgüdüm sağlanarak diş hekimleri tarafından verilecek ağız-diş sağlığı eğitimi ve muayeneleri gebe ve bebek izleminin bir bileșeni haline getirilmeli, aile sağlı̆̆ ekibi tarafından verilen eğitimlerde diş sağlığının da yer alması sağlanmalıdır. Tüm bunların yanı sıra, sosyokültürel bir gelişmeyle birlikte olmadığı sürece sadece eğitime dayalı müdahalelerin sınırlı bir değişim yaratabileceği dikkate alınmalı, eşitsizlikleri bütüncül olarak ele alan çok bileşenli yaklaşımlar izlenmelidir.
Teşekkür

"Anne Adaylarının Ağız-Diş Sağlığının Geliştirilmesi ve Çürüksüz Çocuklar Programı"na verdiği finansal ve lojistik destek için Bornova Belediyesi yönetimine teșekkür ederiz. Bu program, İzmir Diş Hekimleri Odası Toplum Ağız-Diş Sağlığı Komisyonu üyesi olan gönüllü diş hekimlerinin emekleri sayesinde gerçekleștirilebilmiştir. $\mathrm{Bu}$ nedenle Dt. Ahmet Özdikmenli, Dt. Dilek Kaptan, Dt. Esra Özatay, Dt. Filiz Yamaner, Dt. Hülya Doyurum, Dt. İlkay Begeç, Dr. İrem Totu, Dt. Nüket Akkaya, Dt. Olcay Tuna, Dt. Özkan Kandemir, Dt. Özlem Dolar, Dr. Sevgi Akın ve Dt. Suzan Oğuz Atalan'a teșekkür ederiz.

\section{Çıkar çatışması ve anlaşmazlıkları}

Herhangi bir çıkar çatışması veya anlaşmazlık bulunmamaktadır.

\section{Kaynaklar}

1. Boggess KA, Edelstein BL. Oral health in women during preconception and pregnancy: implications for birth outcomes and infant oral health. Matern Child Health J 2006;10:169-174.

2. Armitage GC. Bi-directional relationship between pregnancy and periodontal disease. Periodontol 2000 2013;61(1):160-176.

3. Offenbacher S, Lieff S, Boggess KA, ve ark. Maternal periodontitis and prematurity. Part I: obstetric outcome of prematurity and growth restriction. Ann Periodontol 2001;6(1):164-174.

4. Madianos PN, Lieff S, Murtha AP, ve ark. Maternal periodontitis and prematurity. Part II: maternal infection and fetal exposure. Ann Periodontol 2001;6(1):175-182.

5. Meyer K, Geurtsen W, Günay H. An early oral health care program starting during pregnancy. Results of a prospective clinical long-term study. Clin Oral Invest 2010;14:257-264. 
6. Gomez SS, Weber AA. Effectiveness of a caries preventive program in pregnant women and new mothers on their offspring. Int $J$ Paediatr Dent 2001;11(2):117-122.

7. Plutzer K, Spencer J. Efficacy of an oral health promotion intervention in the prevention of early childhood caries. Comm Dent Oral Epidemiol 2008;36:335-346.

8. Milgrom P, Riedy CA, Weinstein P, ve ark. Design of a community-based intergenerational oral health study: "Baby Smiles". BMC Oral Health 2013;6(13):38.

9. Merrick J, Chong A, Parker E, ve ark. Reducing disease burden and health inequalities arising from chronic disease among indigenous children: an early childhood caries intervention. BMC Public Health 2012;12:323.

10. Medeiros PB, Otero SA, Frencken JE, Bronkhorst EM, Leal SC. Effectiveness of an oral health program for mothers and their infants. Int J Paediatr Dent 2015;25(1):29-34.

11. Lin DL, Harrison R, Aleksejuniene J. Can a prenatal dental public health program make a difference. J Can Dent Assoc 2011;77:b32.

12. American Academy of Pediatric Dentistry Clinical Affairs Committee, Infant Oral Health Subcommittee. American Academy of Pediatric Dentistry Council on Clinical Affairs: Guideline on infant oral health care. Pediatr Dent 2005-2006, 27:68-71.

13. Finlayson TL, Siefert K, Ismail A, Sohn W. Psychosocial factors and early childhood caries among low-income African-American children in Detroit. Community Dent Oral Epidemiol 2007;35(6):439-448.

14. Gibbs L, Waters E, Christian B, ve ark. Teeth tales: A community-based child oral health promotion trial with migrant families in Australia. BMJ Open 2015;5:e007321. doi:10.1136/bmjopen-2014-007321.
15. Ayhan H, Suskan E, Ylldırım S. The effect of nursing or rampant caries on body weight in a pediatric population. J Clin Pediatr Dent 1996 Spring;20(3):209-212.

16. Martins-Junior PA, Vieira-Andrade RG, Correa-Faria P, Oliveira-Ferreira F, Marques LS, Ramos-Jorge ML. Impact of early childhood caries on the oral health-related quality of life of preschool children and their parents. Caries Res 2013;47(3):211-218.

17. Arrow P, Raheb J, Miller M. Brief oral health promotion intervention among parents of young children to reduce early childhood decay. BMC Public Health 2013;20(13):245.

18. Ismail Al, Ondersma S, Jedele JM, Little RJ, Lepkowski JM. Evaluation of a brief tailored motivational intervention to prevent early childhood caries. Community Dent Oral Epidemiol 2011;39(5):433-448.

19. Hallas D., Fernandez JB., Lim LJ. ve ark. OHEP: An Oral Health Education Program For Mothers of Newborns. J Pediatr Health Care 2015;29(2):181-90.

20. Milgrom P, Sutherland M, Shirtcliff RM, Ludwig S, Smolen D. Children's Tooth Decay in A Public Health Program to Encourage Low-income Pregnant Women to Utilize Dental Care. BMC Public Health 2010;18(10):76.

21. Hamilton FA, Davis KE, Blinkhorn AS. An oral health promotion programme for nursing caries. Int J Paediatr Dent 1999;9(3):195-200.

22. Clifford H, Johnson NW, Brown C, Battistutta D. When can oral health education begin? relative effectiveness of three oral health education strategies starting pre-partum. Community Dent Health 2012;29(2):162-167.

23. Harrison, R, Benton, T, Everson-Stewart $S$, Weinstein P. Effect of motivational interviewing on rates of early childhood caries: a randomized trial. Pediatr Dent 2007;29(1):16-22. 
24. Mani AS, John J, Ping WY, Ismail NM. Early childhood caries: parent's knowledge, attitude and practice towards its prevention in Malaysia, oral health care - pediatric, research, epidemiology and clinical practices. In: Virdi M, editor. ISBN: 978-953-510133-8, InTech; 2012 [Online]. Available at: http://www.intechopen.com/books/or al-health-care-pediatric-researchepidemiology-andclinicalpractices/early-childhood-cariesparent-s-knowledge-attitude-andpractice-towards-its-preventioninmalaysia. Accessed June 20, 2015.

25. Bogges KA, Urlaub DM, Moos MK, Polinkovsky M, El-Khorazaty J, Lorenz C. Knowledge and beliefs regarding oral health among pregnant women. J Am Dent Assoc 2011;142(11):1275-1282.

26. Keirse MJ, Plutzer K. Women's attitudes to and perceptions of oral health and dental care during pregnancy. J Perinat Med 2010;38(1):3-8.

27. Habashneh R, Guthmiller JM, Levy S, ve ark. Factors related to utilization of dental services during pregnancy. J Clin Periodontol 2005;32(7):815-821.

28. Özen B, Özer L, Başak F, Altun C, Açıkel C. Turkish women's self-reported knowledge and behavior towards oral health during pregnancy. Med Princ Pract 2012;21:318-322.

29. Kısa S, Zeyneloğlu S. Doğum sonu servisinde yatan kadınların gebelikteki ağız hijyeni alışkanlıkları ve diş hekimine gitme durumları. TAF Prev Med Bull 2013;12(1):65-74.

30. Cidro J, Zahayko L, Lawrence H, Folster $\mathrm{S}$, Mc Gregor M, McKay K. Breast feeding practices as cultural interventions for early childhood caries in cree communities. BMC Oral Health 2015;15:49.

31. Chung LH, Gregorich SE, Armitage GC, Gonzalez-Vargas J, Adams SH. Sociodemographic disparities and behavioral factors in clinical oral health status during pregnancy. Community
Dent Oral Epidemiol 2014;42(2):151159.

32. Boratav K. İstanbul ve Anadolu'dan Sinıf Profilleri. 2. Baskı. Ankara: İmge Kitapevi Yayınları, 2004.

33. Romano RS. Oral health knowledge, attitudes, and behaviors: investigation of an educational intervention strategy with at-risk females. Dissertation in Portland State University, Educational Leadership and Policy. Fall 1-1-2012 [Online]. Available at: http://pdxscholar.library.pdx.edu/cgi/ viewcontent.cgi?article $=1611 \&$ context $=$ open_acces_etds. Accessed April 01, 2015.

34. Cascaes AM, Bielemann RM, Clark VL, Barros AJ. Effectiveness of motivational interviewing at improving oral health: a systematic review. Rev Saude Publica 2014;48(1):142-153.

35. Broughton JR, Maipi JT, Person M, ve ark. Reducing disease burden and health inequalities arising from chronic disease among indigenous children: an early childhood caries intervention in Aotearoa/New Zealand. BMC Public Health 2013;13:1177. 